\section{DEATH OF GEORGE EIBY}

One of New Zealand's most prominent seismologists, George Eiby, died on 26 February 1992 after a long illness.

He was born in Wellington in 1918, and became a cadet in the Department of Scientific and Industrial Research in 1939, training in Seismology and Positional Astronomy. Apart from four years in Britain as a radar mechanic during the Second World War, he remained with the DSIR until 1979, when he retired as Superintendent of the Seismological Observatory.

Following his retirement, he continued his work as an Honorary Research Associate at the Seismological Observatory. He published more than 150 research papers in the fields of seismology, astronomy, and the history of science. His book EARTHQUAKES, which first appeared in 1957, has established itself as a standard work, running to five editions, the most recent in 1989.

He was recognized internationally as New Zealand's foremost authority on historical earthquakes, and was an active member of the IASPEI/UNESCO Working Group on Historical Seismograms and Earthquakes. At the time of his death, he was engaged in a major study of New Zealand's largest historical shock, the magnitude 8.1 West Wairarapa earthquake of 1855 . In addition, he had recently completed a book on volcanoes, which is expected to be published shortly.

Throughout his career, he was very active in fostering the development of seismology, not only in New Zealand, but also in the wider South West Pacific region. He was the motivating force behind the Seismological Society of the South West Pacific, and served as convener and Newsletter editor for the Society from 1968 to 1974 . He also served on several UNESCO Seismological Missions to Southeast Asia and the South West Pacific.

His non-scientific interests were extremely wide. He was an authority on the history of theatre buildings, stage scenery, and stagecraft, and produced or designed more than a hundred plays for local drama societies. He was a founder of the Film Society movement in New Zealand, was a keen musician, and exhibited photographs and sketches. He was also an enthusiastic linguist, historian, and collector of books important to the early development of geophysics.

Martin Reyners

1992 March 03

\section{A TRIBUTE TO GEORGE EIBY \\ Warwick D.Smith \\ Chief Seismologist \\ DSIR Geology and Geophysics}

(Dr Smith was unable to attend George Eiby's funeral on 1992 March 2. This tribute was kindly read for him by Dr Euan Smith).

I am genuinely sorry not to be able to make these comments in person on this occasion. I have known George for more than 20 years, and although that is a shorter association with him than many of you have had, it is hard for me to imagine the Seismological Observatory without him a part of it.
George once told me that he didn't like eulogies, so I don't propose to give one. In recent years, he found that he was attending quite a lot of funerals, and I suppose that will happen to most of us as we get older, but he did say that he saw little purpose in a long list of the person's fine qualities or achievements. And I think I know what he meant. Several years ago I was at a scientific meeting when we were informed that a man who had previously been a regular attender at that meeting had died since we had last met. So what did we do? We stood for a minute or two in silence, then went on with our meeting. And I couldn't help thinking "Is this what his life was about? Is this all he lived for?"

So today I don't want to give a eulogy. Instead I want to talk about some things I have learnt from George. There are three things in particular.

First, all of you who have worked with George will know how careful he was in his work. Especially if you have written scientific papers, and have asked him to comment on the manuscript. You knew that you would not get it back until he had been over it with a magnifying glass, and there would be pages of comments added, noting inconsistencies of style, expression, and weaknesses in the argument. He wrote his own papers with the same care. Every sentence was turned inside out, and back again, to see if there was a better way of expressing it. And you knew that if you criticised anything, you had better have a good case because he was sure to have considered your objection already. The same attitude prevailed in his scientific investigations. Careful, painstaking work paid off in the end. It is an important lesson to learn.

The second lesson is one that I fear I have not learned very well. He was a man of very wide interests. Let me quote from the newly published edition of "Who's Who in New Zealand", in which his interests are listed as the following: books, drama, cinema, music, photography, painting, history of physical sciences, collecting historically important works on geophysics and history of theatre buildings, scenery and stagecraft; playing recorders, languages, travel, swimming. Now it is very easy to say that, as a single man with no family commitments, he had time for these things. And that is true. But he also had the interest in them, and the desire to devote time to enriching his life by pursuing them. It seems to me that a man or woman whose career is their only interest is a very limited person.

The third lesson comes from the recent months since George's medical condition became serious. From the time he got the news, he began to set his affairs in order. Sorting out his office, setting to one side those things that were personal and leaving those that belonged with the Observatory. He could have reacted angrily, as many people do to such news, but he didn't. This wasn't defeatism, it was realism. He was simply accepting what he had come to realise was inevitable, and was responding in a pragmatic way. It seems to me that we can conserve a lot of physical and nervous energy by acting like that. I hope I have learnt that lesson too.

So I am grateful to George for these things, and many others. I hope there are things that other people can learn from each of us. If that is true, then reflections at a time like this can be very valuable. 